\title{
Praktik Pernikahan dalam Masyarakat Lokal: Agensi versus Agama
}

\author{
Budiman Pohan, ${ }^{1 *}$ Muhamad Fadhil Nurdin² \\ ${ }^{1}$ Program Studi Magister Sosiologi Universitas Padjadjaran Bandung, ${ }^{2}$ Program Studi \\ Sosiologi Universitas Padjadjaran Bandung - Indonesia
}

\begin{abstract}
This study aims to describe the dialectical process between local agents and religious structures in the practice of marriage in Padang Sidempuan. The research method is qualitative descriptive with a case study design that focuses on narrating the objective conditions of agent and structure duality. Informants were chosen purposively, supported by observational data, interviews, and documentation. Data analyzed through the process of collection, reduction, exposition, verification, and conclusion. The results showed that: 1) Conceptually, the practice of marriage experienced practical distortions that were configured through consensus of sharia and local elites; 2) the practice of marriage is a phenomenon of the duality of agents and structuring each other; 3) agent habitus is dominated by Mandailing culture through power relations and surplus capital of the local elite compared to the sharia procedure of religious structure. However, the competence of agents is able to compress marital rules into semi-complex; 4) the importance of promoting religious habituation strategies through internalization and dissemination of alternative sharia marriage practices.

Penelitian ini bertujuan untuk mendeskripsikan proses dialektika antara agen lokal dan struktur keagamaan dalam praktik perkawinan di Padang Sidempuan. Metode penelitian yang digunakan adalah deskriptif kualitatif dengan rancangan studi kasus yang menitikberatkan pada penuturan kondisi objektif dualitas agen dan tatanan. Informan dipilih secara purposif yang didukung dengan data observasi, wawancara, dan dokumentasi. Data dianalisis melalui proses pengumpulan, reduksi, eksposisi, verifikasi, dan penarikan kesimpulan. Hasil penelitian menunjukkan bahwa: 1) Secara konseptual, praktik perkawinan mengalami distorsi praktis yang dikonfigurasikan melalui konsensus syariah dan elit lokal; 2) praktek perkawinan adalah fenomena dualitas agen dan penataan satu sama lain; 3) kebiasaan agen didominasi oleh budaya Mandailing melalui relasi kekuasaan dan kelebihan modal elit lokal dibandingkan dengan tata cara syariah dalam struktur keagamaan. Namun, kompetensi agen mampu memadatkan aturan perkawinan menjadi semi-kompleks; 4) pentingnya mempromosikan strategi pembiasaan ajaran agama melalui internalisasi dan sosialisasi alternatif praktik perkawinan syariah.
\end{abstract}

Keywords: habitus-field; Padang Sidempuan; marriages; social practice

*Korespondensi Penulis: Budiman Pohan (budiman18001@mail.unpad.ac.id), Program Studi Magister Sosiologi Pascasarjana FISIP, Universitas Padjadjaran Bandung, Jl. Bukit Dago Utara No.25, Dago, Kecamatan Coblong, Kota Bandung, Jawa Barat 40135. 


\section{Pendahuluan}

Sebagai umat Islam, pernikahan adalah ritus yang dilalui dua insan manusia untuk menyempurnakan jati dirinya sebagai makhluk yang berpasangan. Oleh karena itu, penting untuk mengikat rasa cinta dan kasih sayang calon pasangan melalui prosedur-prosedur syar'i dan konstitusional (Atabik and Mudhiah 2014). Komitmen di antara calon pasangan pengantin adalah hal yang sangat penting dalam meraih manfaat proses sosial berupa terpenuhinya kebutuhan inklusi, afeksi, dan kontrol sosial dalam bingkai rumah tangga (Wulansari 2013; Yuniariandini 2016).

Bukan perkara yang mudah merumuskan komitmen dan perwujudannya dalam pernikahan yang abadi bagi kedua belah pihak, karena akan melibatkan elemen-elemen sosial di internal dan ekstenal keluarga. Di sinilah muncul sejumlah polemik bagi sebagian anggota masyarakat, terkait dengan akseptabilitas pernikahan berdasarkan selera agen lokal yang belum tentu relevan bagi agen lainnya. Di sisi lain, agama (Islam) telah menawarkan alternatif praktik pernikahan yang sederhana. Oleh karena itu, akar permasalahan tersebut bagi peneliti layak untuk diteliti lebih lanjut.

Berdasarkan tinjauan penelitian-penelitian terdahulu, terdapat sejumlah hal yang dapat kita simak terkait praktik pernikahan dalam masyarakat lokal. Pada aspek akademis, isu-isu pernikahan telah banyak diurai dengan pendekatan Islam kultural (Aziz 2017; Noorthaibah 2012; Shodiq 2008; Wekke 2013). Beberapa penelitian lain berfokus upaya meradikalisir substansi, fungsi, dan konsekuensi dari unsur-unsur pernikahan
(Anwar 2017; Arifin 2018; Hairani 2018; Muhadi 2015).

Pada kajian peneliti terdahulu ditemukan adanya praktik-praktik pernikahan yang saling bertentangan antara agama dan budaya. Sejumlah praktik pernikahan di tingkat lokal terindikasi memuat penyimpangan, seperti dalam biaya pernikahan yang di luar kewajaran dan cenderung transaksional (Adiningsih 2016; Elvira 2014; Huda and Evanti 2019; Ilman 2016; Prawiro 2013; Rahayu and Yudi 2015).

Penyimpangan lainnya seperti tata cara lokal yang belum memenuhi prasyarat syar'i (Amalia 2017), dominasi agen lokal dalam menentukan calon pasangan (Anwar 2017; Hairani 2018) dan pelaksanaan ritusnya (Anwar 2017; Kartikasari 2019; Larasaty, Marzam, dan Syeilendra 2013; Muhadi 2015). Anas (2010) melihat bahwa nuansa pernikahan semakin diarahkan pada antroposentrisme dibandingkan dengan ketentuan hukum Islam.

Islam sesungguhnya telah mengatur pernikahan secara prinsipil dan teknis. Adab pernikahan secara global sepatutnya disadari seseorang sejak memikirkan pernikahan sampai terbentuknya keluarga (al-Atsari dan al-Jauziyah 2007). Pernikahan memuat kemaslahatan dunia dan akhirat, maupun individu dan sosial, maka pernikahan seyogianya dilaksanakan sesuai tuntunan syariat. Oleh karena itu, berbagai pelanggaran yang berkait dengan pelaksanaan hingga berakhirnya pesta pernikahan dapat merusak rasa syukur atas kemaslahatan yang telah diraih (Baaz dan al-Utsaimin 2002:9-11). Hal ini mengisyaratkan bahwa praktik pernikahan dalam konteks agama perlu dilihat secara integral 
dengan mempertimbangkan orisinalitas pelaksanaannya.

Lokus penelitian berada di Padang Sidempuan Sumatera Utara yang didominasi oleh penduduk beretnis Mandailing dan beragama Islam. Pernikahan adat Mandailing menjadi praktik pernikahan yang sering dilakukan oleh masyarakat setempat. Adat pernikahan ini masih eksis diselenggarakan (Dalimunthe 2012, 2016), meskipun telah mengalami perubahan karena mengalami akulturasi (Harahap 2016, 2017; Krisna and Desti 2015; Nurhakimah 2018), modernisasi dan kepraktisan dalam implementasinya (Anisah 2017; Nasution 2011).

Dalam perkembangannya praktik pernikahan adat di Kota Padang Sidempuan belum mengarah ke pernikahan sesuai syar'iat. Oleh karena itu masih dijumpai beberapa ketidaksesuaian praktik pernikahan dalam masyarakat lokal. Asumsi yang dibangun peneliti adalah bahwa praktik pernikahan cenderung berasaskan lokalitas dengan mengekstrak esensi agama semata. Padahal, prinsip maupun prosedur pernikahan secara komprehensif telah diatur di dalam agama, sehingga, kadar agama telah mengalami reduksi atas inisiatif agen lokal.

Untuk memotret persoalan tersebut, peneliti menggunakan pendekatan sosiologi Islam. Sosiologi Islam (sosiophologi) memiliki keterkaitan dengan definisi sosiologi yang dikemukakan oleh Syariati, sebagaimana yang dikutip oleh Abidin dan Safe'i (2003:27) bahwa sosiologi adalah keyakinan khas manusia yang bersumber pada akumulasi empiris dari kiblat pemahaman individu tentang lingkungan sosial serta implikasinya. Sedangkan Ilyas B.A. Yunus dalam Abidin dan
Safe'i (2003:27) mendefinisikan sosiologi sebagai riset mutakhir melalui peningkatan observasi multidimensi, seperti manusia, behavioral, ritusritus, TBC (takhayul, bidah, churafat), politik, dan ekonominya. Kuntowijoyo (2001:28-29) merumuskan enam komponen strukturalisme transendental dalam sosiologi Islam, yaitu: 1) Islam sebagai struktur; 2) metodenya relevan dengan Islam masa kini; 3) Islam bersifat transformatif tanpa kehilangan identitasnya; 4) umat Islam berkewajiban beradaptasi atas dinamika lingkungan dan interaksinya; 5) antitesis bahwa Islam sebagai agama yang monoton; dan 6) kajiannya relevan dengan persoalan multidimensi di era modern.

Sosiologi Islam memformulasikan pendekatan rasional dan liberal serta menambahkan instrumen transendental sebagai episentrumnya, sehingga, meski terjadi dialektika argumen, solusi terbaik dalam membangun sintesa adalah dengan mengembalikannya pada al-Qur'an dan Hadis (Jauhari 2012:27).

Praktik pernikahan tidak serta-merta dibentuk oleh unsur sosial-budaya, tetapi muatan spiritual telah mewarnai kaidah pernikahan secara struktural. Peneliti berasumsi bahwa pendekatan sosiologi Islam tepat digunakan karena konsentrasinya yang berfokus pada fenomena keislaman dan bergerak dinamis seiring dengan perkembangan masyarakat.

Praktik pernikahan menjadi salah satu "spealisasi" Bourdieu dalam melihat dunia sosial. Penelitian etnografinya tentang pola pernikahan endogami orang Barbar Aljazair yang diatur oleh elite lokal melalui ideologi, preferensi, dan strategi serta wajib ditaati oleh agen lain Jenkins 
2016:50). Relasi agen dan struktur saling menstrukturisasi serta melibatkan komponen habitus, modal, arena, dan konsekuensi distingsi. Akumulasi konsep inilah yang dinamakan praktik sosial (Adib 2012).

Tujuan penelitian ini untuk menganalisis: 1) perbedaan pernikahan dalam perspektif kultural dan syariat; 2) operasionalisasi konsepsi teori Bourdieu dalam kerangka praktik pernikahan; 3) hasil temuan praktik pernikahan masyarakat lokal; 4) praktik pernikahan dalam masyarakat lokal; dan 5) alternatif reproduksi sosial dalam pembiasaan praktik pernikahan agama.

Untuk prosedur metodologisnya, peneliti memilih format deskriptif yang berfokus pada tulisan naratif serta didukung fakta dan data (Anggito and Setiawan 2018:11). Sedangkan desain penelitian berbentuk studi kasus yang menitikberatkan pada fenomena terkini tanpa kontrol ilmiah (Bryman 2004:31; Sekaran 1993:43). Metode beserta desain tersebut dipilih untuk menarasikan proses dialektis agen dan struktur praktik pernikahan dalam masyarakat lokal. Secara berkala, data dikumpulkan melalui proses observasi, wawancara, dan dokumentasi. Informan dipilih secara purposif, yakni anggota masyarakat Padang Sidempuan yang bersedia untuk bertukar pikiran tentang pengalamannya ketika melangsungkan pernikahan. Data yang diperoleh dianalisis secara interaktif menggunakan prinsip Miles \& Huberman melalui prosedur koleksi, reduksi, eksposisi, verifikasi, dan konklusi data dalam bentuk laporan. Uji kualitas data berupa triangulasi sumber untuk memvalidasi proses dialektis agen lokal dalam menyikapi praktik pernikahan di lingkungannya.

\section{Pernikahan dalam Bingkai Syariat dan Kultural}

Pernikahan atau perkawinan adalah persekutuan laki-laki dan wanita yang diakui secara hukum dan agama berdasarkan standar lembaga pernikahan (Tutik 2006). Dalam Kompilasi Hukum Islam, pernikahan merupakan suatu ikatan disertai akad yang legal dan kuat sebagai manifestasi ibadah atas perintah Allah. Rukun pernikahan meliputi: 1) calon pasangan (pria dan wanita); 2) wali; 3) dua saksi; dan; 5) akad (Mathlub 2005; Naim 2008; Nuruddin and Tarigan 2004). Sedangkan syarat pernikahan meliputi: 1) izin pernikahan dan tidak diskriminatif; 2) memenuhi standar usia pernikahan; 3) pernikahan bukan antarhubungan darah dan persusuan; 4) pernikahan bukan beda agama; dan 5) pemberitahuan akan dilangsungkannya pernikahan. Semua syarat tersebut telah diatur dalam dalil-dalil konstitusi (Tutik 2006).

Secara administratif, pernikahan memiliki beberapa ketentuan, yaitu: 1) pelaksanaan pernikahan dilakukan pasca hari kesepuluh sejak pengumuman pernikahan; 2) tatacara pernikahan diatur berdasarkan agama dan kepercayaan yang dianut; 3) perwakilan keluarga dan pemerintah hadir sebagai saksi untuk menyaksikan serta menandatangani akad dan akta pernikahan; dan 5) status pernikahan sah secara legal-formal (Peraturan Pemerintah Nomor 9 Tahun 1975).

Berdasarkan informasi tersebut, pemerintah mengakui adanya hak bagi pihak yang menikah untuk melangsungkan pernikahan, tetapi institusi agama yang ada jarang mempromosikan pernikahan syar'i. Padahal, Islam juga mengkonfi- 
gurasi hal tersebut dari aspek prinsip maupun praksisnya.

Beberapa catatan kritis dikemukakan oleh pihak-pihak yang menyatakan adanya hal yang dipandang tidak sesuai dengan syariat berkait dengan prosesi pernikahan antara lain 1) menghindari pernikahan; 2) menangguhkan pernikahan tanpa alasan syar'i; 3) pelamar tidak diizinkan melihat calon istri secara syar'i; 4) mempertinggi mahar; 5) ritus dan cincin tunangan; dan 6) prawedding. Penyimpangan saat prosesi pernikahan: 1) formalitas pernikahan; 2) keluarnya kaum wanita dengan memakai minyak wangi; 3) ikthilath; 4) berfoto ria; 5) berwalimah tanpa mengundang fakir miskin; 6) boros serta pamer; dan 7) mengundang biduan/biduwanita yang diiringi musik. Penyimpangan pasca pernikahan: 1) ucapan ala jahiliyah; 2) bulan madu; dan 3) agenda lain yang tidak disyariatkan (Baaz dan Utsaimin 2002). Argumentasi peneliti memilih konsepsi yang menitikberatkan pada konteks adab, batasan, maupun bid'ah-bid'ah dalam praktik pernikahan dengan maksud untuk menghadirkan sisi kontras atau inversi praktik pernikahan yang dilakukan masyarakat lokal selama ini.

Pernikahan orang Batak terkhususnya Mandailing adalah pernikahan eksternal marganya (eksogami) dengan prasyarat tertentu. Pernikahan semarga tidak dapat ditolerir, dan jika dilakukan akan terjadi sumbang (incest) di dalam satu marga. Apabila perbuatan tersebut dilakukan oleh mereka yang masih memiliki hubungan kekerabatan, maka keduanya diusir dari huta (teritori minor hukum dan adat), dilepas dari ikatan marga atau bahkan dibunuh (Ypes 1932:14). Idealnya, pernikahan terdahulu dikenal dengan istilah marboru ni tulang. Jadi, sistem pernikahan patrilineal cross cousin dipandang terlarang. Pernikahan paralel cross cousin dipandang namarito, artinya bersaudara-saudari. Maksud larangan ini adalah untuk memproteksi partuturan (hubungan kekerabatan) dari keturunan yang terbalik-balik, serta menghindari hubungan sosial di dalam struktur masyarakat agar tidak kacau atau rusak.

Proses pernikahan adat Mandailing dimulai dari lamaran, dan pihak keluarga pria datang menemui keluarga pihak wanita yang dilakukan oleh pihak laki-laki dan perwakilannya (marhusip). Jika diterima, maka berlanjut pada sesi negosiasi (marhata sinamot). Negosiasi ini membahas: 1) jumlah mahar (tuhor), seperti harta, barang, dan ternak; dan 2) jumlah hadiah yang diterima pihak keluarga dan kerabat wanita (Simanjuntak 2006:114). Prosesi pernikahan dihadiri oleh keluarga dan kerabat di kedua belah pihak sekaligus penyerahan mahar dan hadiah. Sementara itu, hidangan pernikahan adalah kerbau yang disembelih dan bagian-bagian tertentu dari binatang tadi diserahkan kepada para kerabat (jambar) (Koentjaraningrat 2004).

Pesta pernikahan dapat berlangsung satu hari, pagi sampai sore, bahkan malam hari. Jika pesta pertunjukan selesai, maka dilanjutkan dengan pesta pemuda-pemudi (naposo) sebagai simbol dengan pengantin wanita karena telah berstatus sebagai kelompok orangtua (natua-tua). Bagi pengantin laki-laki diharuskan menyerahkan hadiah kepada pemuda (harta atau barang. Setelah pesta hampir usai di pagi hari, biasanya para gadis-gadis menangisi pengantin wanita (Simanjuntak 2006:114-15).

Penggambaran ritual perkawinan adat ini penting disampaikan sebagai informasi awal tentang ritual khas adat Mandailing. Beberapa 
pustaka terkait akan mengayakan penggambaran mengenai fenomena adat ini, selain hasil wawancara dengan para informan.

\section{Praktik Sosial}

Praktik sosial adalah konsepsi teoritis yang menjelaskan proses dialektis antara agen dan struktur yang sifatnya tidak murni objektif maupun konstruktivisme total (Ritzer and Douglas 2011:578). Tentunya, peran sentral kerangka habitus, modal, dan arena/ranah amat penting dalam memotret realitas dialektis (Ritzer and Douglas 2011; Swartz 1997).

Habitus merupakan piranti interpretasi dalam mengidentifikasi realitas dan mereproduksi berbagai varian praktik kehidupan sehari-hari (Haryatmoko 2016:41). Habitus memiliki tujuh karakteristik unik, antara lain: 1) inkulkasi, habitus sebagai produk historis bersumber dari repetisi praktik yang berlangsung lama; 2) struktur yang distrukturkan, bahwa habitus merupakan kontinum dari piranti struktur lama dan direproduksi pada kondisi sosial tertentu; 3) struktur yang menstrukturkan, artinya habitus berkontribusi dalam memateralisasikan struktur dalam bentuk yang berbeda; 4) transposisi, bahwa habitus dapat beralih pada kondisi sosial lainnya; 5) pra-sadar, bahwa habitus dapat berbentuk spontanitas yang tidak disadari namun dapat dikaitkan dengan faktor historis; 6) stabil serta berpola, bahwa habitus bukanlah perangkat kognisi yang mengompulsi peraturan, namun tetap memprosesnya terlebih dahulu; dan 7) visiun, artinya habitus dapat mengonstruksi tujuan namun tidak otomatis dibarengi dengan kesadaran penuh dan kapabilitas yang spesifik (Jenkins 2016:116-21).
Habitus menjadi basis karakter agen yang mengalkulasi stabilitas behavioral dan modalitas praktiknya untuk berfokus pada improvisasi, bukan pada loyalitas aturan (Haryatmoko 2016:41). Pernyataan tersebut melibatkan konsep lainnya dalam praktik sosial, yakni modal. Modal adalah kapasitas yang membangkitkan kemampuan agen dalam bertindak dengan empat komposisi, antara lain: 1) modal finansial, yakni stok ekonomis yang dimiliki; 2) modal sosial, yakni relasi sosial antarorang yang dipandang bernilai; 3) modal kultural, berupa wawasan yang legitim; dan 4) modal simbolik, adalah tingkat harkat dan martabat yang diraih (Ritzer and Douglas 2011:583).

Habitus dan modal beroperasi dalam konsep arena yang dianalogikan sebagai struktur integratif dan multidimensi serta membentuk peluang hegemoni dalam masyarakat. Kadangkala disebut sebagai arena perjuangan yang menentukan posisi agen berdasarkan kuantitas dan kualitas modal dalam meraih kelas (Bourdieu 1993:9).

Habitus, modal, dan ranah turut disupport oleh konsep lain seperti kekuasaan simbolik, strategi, dan perebutan jenis modal (Bourdieu 1986). Konsep-konsep ini penting dalam menjelaskan secara komprehensif bagaimana praktik sosial berlangsung. Sehingga dimungkinkan untuk mengeksplorasi identitas orisinil suatu masyarakat, mulai dari watak subjektif individual hingga karakteristik struktur objektifnya (Harker, Mahar, and Wilkes 2005:xxii-xxiv).

Jika dikaitkan dengan kasus yang diteliti, teori praktik sosial dipilih dengan asumsi terdapat dualitas prinsipil dan prosedural dalam praktik pernikahan antara agensi lokal dan agama. Hal ini memicu dialektika yang mesti dijawab secara 
metodologis, apa dan bagaimana motif serta manfaat dari agensi lokal mengatur tata cara pernikahan dan di mana posisi agama diberlakukan. Sedangkan diketahui bersama, bahwa agama (Islam) juga memberikan pengaruh praktik pernikahan secara komprehensif dan semestinya diaktualisasikan oleh penganutnya. Maka, tidak ada alasan menafikan posisi agama dalam ritus-ritus pernikahan.

Berdasarkan konsep dan teori yang telah dipaparkan sebelumnya, dapat disusun suatu kerangka pemikiran. Konsep-konsep praktik sosial Pierre Bourdieu dapat dipadukan dengan muatan isu-isu pernikahan di Padang Sidempuan dengan penjabaran argumentatif. Rincian penjelasannya adalah sebagai berikut:

Pertama, habitus. Komponen ini disimbolkan dengan pointer yang mengitari agen lokal dan struktur agama. Karakteristik agen lokal, antara lain: 1) aktivitas sehari-hari agen turut merespon praktik pernikahan di lingkungannya. Umumnya direproduksi oleh agen lokal lainnya yang berbasis kultural (adat-istiadat); 2) agen berupaya mendefinisikan simbol-simbol pernikahan serta aplikasinya tergantung kapasitas modal yang dimiliki; dan 3) pemahaman agen lokal terus berkembang disesuaikan dengan situasi praktik pernikahan terkini. Meski demikian, intervensi agen lokal lainnya tetap ingin melestarikan nilainilai kearifan yang ada. Sedangkan karakteristik struktur agama, antara lain: 1) berkaitan erat dengan sacred dan profan, yakni basis utama muatan agama yang memutuskan status amalan penganutnya. Sacred menarasikan kesakralan ibadah yang mesti dipenuhi, sedangkan profan memuat keharaman suatu perbuatan yang mesti dijauhi; 2) Manifesto praktik pernikahan semesti- nya pararel dengan dominasi elite agama di masa lampau (Salaf). Merekalah kiblat utama umat dalam mereproduksi praktik pernikahan syar'i; dan 3) agama tidaklah bersifat statis, melainkan dinamis selama linier dan adekuat. Oleh karena itu, tradisi pernikahan syar'i dapat dikreasikan oleh agen tanpa mendelegitimasi prinsi-prinsip yang berlaku. Habitus adalah refleksi kecenderungan agen dalam memaknai dunia pernikahan, baik agen lokal dan struktur agama akan saling memengaruhi agen dalam memutuskan jenis praktik pernikahan bagi dirinya. Atau sebaliknya, kemampuan habitus bisa saja mengadaptasikan diri agen pada pertimbangan logis untuk memilih praktik pernikahan yang proporsional bagi dirinya. Tidak mesti mutlak berpangku pada salah satu unsur yang memengaruhinya.

Kedua, ranah atau arena. Merupakan wahana yang menjadi keunggulan agen dalam merefleksikan praktik pernikahan. Ranah bagi setiap agen memiliki kadar keunggulannya masingmasing dan tidak bisa disamaratakan. Agen akan mempertimbangkan jenis praktik pernikahan yang relevan bagi dirinya berdasarkan kemampuan modal yang dimiliki. Entah itu cenderung dipengaruhi oleh agen lain, struktur, maupun mendifusikan dua perspektif tadi ke arah yang lebih realistis. Hal ini juga berkaitan dengan selera agen dalam merumuskan potensinya di spektrum social field maupun intellectual field.

Ketiga, modal. Komponen ini tergantung pada level selera yang dianut oleh agen. Hal mudah bagi agen yang memiliki kapasitas mumpuni dalam merealisasikan praktik pernikahan yang rumit dan berada pada koridor adat-istiadat. Di sisi lain, agen yang cenderung pada struktur 
agama akan mempertimbangkan batasan-batasan syar'i yang telah diatur dan cenderung inversif dengan pemahaman agen lokal. Tetapi, modal, menurut peneliti adalah komponen yang tidak dapat dipisahkan, yang saling terintegrasi dan turut menentukan versi praktik pernikahan sesuai dengan selera agen. Sifat agen pun tidaklah sama, salah satu atau sebagian modal dapat bersifat stagnan, surplus, atau bahkan defisit tergantung pada kapasitas dan adaptasi agen dari masa ke masa.

Praktik adalah akumulasi dari intervensi habitus, arena, dan modal di antara agen dengan struktur. Pada bagian inilah, peneliti akan menarasikan proses-proses dialektis tersebut berdasarkan data-dan fakta yang telah diperoleh. Peneliti tidak menutup kemungkinan akan me- nawarkan konsep yang proporsional dengan menempatkan struktur agama sebagai komponen yang strategis dan worth it untuk direalisasikan oleh agen, dengan istilah habitualisasi struktur. Agama sesungguhnya begitu kompleks, di dalamnya terdapat habitus-habitus yang terpelihara sejak era salaf dari masa lampau hingga sekarang dengan arena dan modal yang bervarian. Bahkan, masih mumpuni untuk direproduksi oleh agen di masa sekarang. Ini sebagai langkah diversifikatif dalam mengkritisi teori praktik sosial Bourdieu dengan fenomena yang berbeda.

Simplifikasi argumentasi teoritis yang dibangun peneliti untuk menganalisis praktik pernikahan juga tertuang dan dapat disaksikan dalam bagan kerangka konseptual.

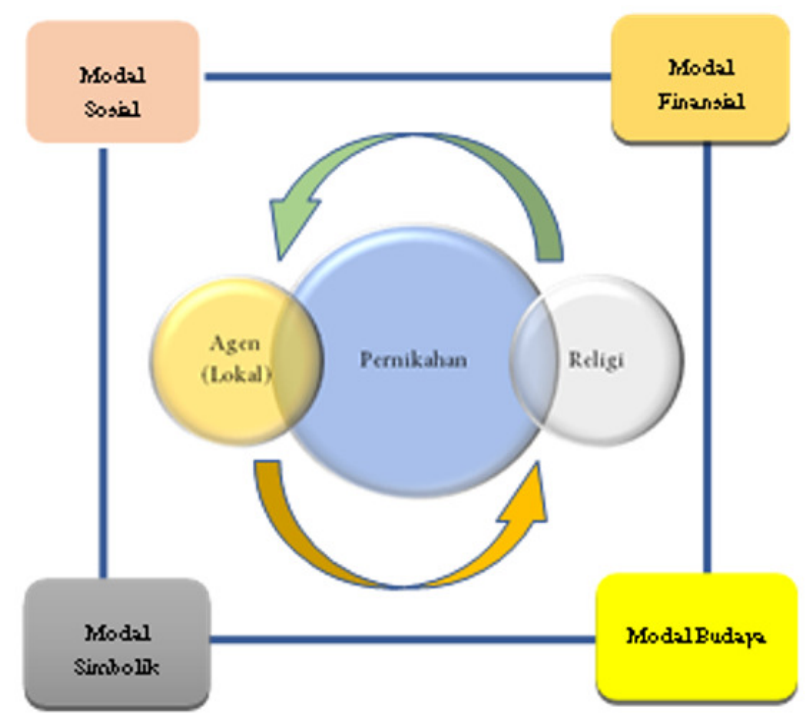

Gambar 1.

Bagan Kerangka Konseptual 


\section{Praktik Pernikahan Masyarakat Lokal di Kota Padang Sidempuan}

Praktik pernikahan di Kota Padang Sidempuan relatif dinamis. Praktiknya cenderung berciri adatistiadat, agama, maupun keduanya. Hal ini dapat pula disebabkan kedudukan yang tidak ekuivalen di setiap elemen masyarakat lokal. Untuk mengetahui status dari proses dialektis tersebut, maka peneliti mengorganisir seluruh hasil penelitian dalam bentuk narasi yang komprehensif. Identitas informan hanya berupa inisial untuk menjaga kerahasiaan personal.

Informan penelitian EMP, NS, AAP, YHP, dan BKA memiliki kemiripan motivasional untuk menikah karena panggilan iman, kecukupan usia, dan modal untuk melangsungkan pernikahan. Setiap informan memiliki keunikan tersendiri dalam memulai proses lamaran. Informan EMP dan AAP terlebih dahulu melakukan kontak tidak langsung untuk berkunjung ke rumah pihak keluarga wanita yang hendak dipinang. Jika kondisi memungkinkan, perjumpaan dapat dilakukan dengan perwakilan anggota keluarga atau dapat juga diwakili oleh keluarga lain. Jika proses lamaran diterima, maka tahapan perundingan yang mesti disepakati oleh kedua belah pihak. Bagi informan AAP dan YHP, terdapat kesulitan dalam menentukan biaya nikah karena dinilai terlampau tinggi. Sempat alot dan meminta keringanan biaya hingga terjadi penundaan, namun dengan terpaksa ketentuan biaya mesti dipenuhi. Informan EMP dan NS tidak menemui kendala dalam perundingan karena kedua belah pihak memaklumi kadar kesanggupan calon pelamar. Informan BKA menetapkan ketentuan mahar tanpa diintervensi oleh keluarga dan disetujui oleh keluarga pelamar.

Informan EMP, NS, AAP, dan YHP memilih melangsungkan pernikahan dengan pendekatan kultural dengan kadar yang beragam. EMP dan NS sepenuhnya menggunakan prosedur adat. AAP dan YHP bernilai adat karena biaya pernikahan yang diminimalisasi. BKA justru mengaplikasikan pernikahan syar'i. Karena itu, kontribusi sosial dan finansial dari tokoh adat, dan keluarga terhadap EMP, NS, AAP, dan YHP sangat signifikan, dibandingkan dengan BKA. Pernikahan BKA yang minim keterlibatan tokoh adat, cukup melibatkan keluarga, kerabat, dan pemuka agama.

Pada proses dan akad dalam resepsi pernikahan, mayoritas informan mengakui telah memenuhi persyaratan administratif pernikahan, tetapi juga mengakui bahwa praktik pernikahan yang selama ini dilakukan masih belum memenuhi prasyarat syar'i, kecuali dari aspek fiqh. Sedangkan informan BKA berupaya mengapli-

Tabel 1:

Aspek Syariat dan Kultural dalam Pernikahan

\begin{tabular}{lll}
\hline Informan & Syariat & Kultural \\
\hline EMP & Administratif & Totalitas \\
NS & Administratif & Totalitas \\
AAP & Administratif & Akad; walimah; Mahar dan biaya nikah \\
YHP & Administratif & Akad, walimah, mahar dan biaya nikah \\
BKA & Administratif; sunnah & Tidak beradat-istiadat \\
\hline
\end{tabular}


kasikan praktik pernikahan syar'i, akan tetapi masih ditemukan tidak kesesuaian berupa sesi berfoto melalui photoboot (karena ada ulama yang mengharamkan berfoto).

Aktivitas yang dijalani informan setelah acara pernikahan adalah melangsungkan tradisi menyambut pengantin di kediaman pihak keluarga laki-laki. Sedangkan informan BKA tidak melakukan acara penyambutan karena langsung tinggal serumah dengan suami. Kendati demikian, seluruh informan menikmati sekaligus menyadari betapa melelahkannya prosesi pernikahan. Selain itu, adanya fragmen-fragmen yang dipandang belum syar'i tidak bisa lepas dari pengaruh dominan tokoh-tokoh adat. Pihak keluarga belum memiliki basis yang kuat untuk mempertahankan prinsip yang tidak sesuai dengan lingkungan.

Data menunjukkan bahwa sebenarnya informan menyadari beberapa praktik dalam perkawinan tidak masuk dalam koridor syar'i, misalnya ikhtilath, berjabat tangan dengan yang nonmahram, dan mengundang penyanyi (biduwan/ biduwanita). Seluruh informan menyadari bahwa penting untuk melangsungkan pernikahan syar'i karena simpel dan jauh dari mudarat. Namun demikian, informan menyadari bahwa ritual perkawinan merupakan hasil dari kesepakatan kedua pihak. Oleh karena itu, dengan perbedaan perspektif dan keinginan masing-masing keluarga tidak mudah untuk memaksakan keinginan dari salah satu pihak, apalagi dengan tradisi lokal yang begitu kuat.

\section{Praktik Pernikahan dalam Masyarakat Lokal}

Dalam praktik sosial Bourdieu, habitus berfungsi sebagai perangkat kognitif agen, mencakup pengetahuan dan pemahaman seseorang tentang dunia sosial (Harker et al. 2005:14).

Setiap agen yang hendak menikah diatur oleh pemahaman dan pengalaman struktur adat agar matang dalam bersikap. Yuniariandini (2016) menekankan bahwa kesiapan mental menjadi salah satu faktor penting untuk dapat melestarikan pernikahan di masa mendatang. Pengetahuan pernikahan dikonstruksi oleh agen elite lokal dengan membebankan warisan budaya pernikahan kepada generasi selanjutnya.

Karena itu, pembelajaran secara historis dengan melacak pengalaman otentik agen-agen yang telah menikah dapat menambah pengetahuan bagi orang-orang yang hendak menikah. Dengan kata lain, habitus turut dibentuk melalui sosialisasi kondisi objektif yang berkontribusi dalam menstrukturkan praktik (Harker et al. 2005:15).

Ungkapan tersebut pararel dengan kasus praktik pernikahan di Kota Padang Sidempuan, teridentifikasi bahwa kecenderungan psikis agen didominasi oleh agen elite lokal yang memiliki modal kultural dan simbolik yang memadai dalam menentukan kriteria pernikahan. Di sisi lain, peluang untuk menghasilkan pernikahan syar'i juga ditunjukkan oleh agen minor karena telah dibekali oleh pemahaman yang terbuka dan diperkaya dengan pengetahuan agama.

Pernyataan tersebut diartikan Bourdieu sebagai hubungan dominasi simbolik melalui kepemilikan modal. Perbedaan strategi, kualitas, dan kuantitas modal inilah yang membedakan hierarki seseorang dalam kelas sosial (Haryatmoko 2016:45). Ukurannya pun dapat dilihat berdasarkan p-engetahuan, kehormatan, kekuasaan, dan kekayaan (Soekanto 2005:237). 
Ranah atau arena, yakni tempat atau wahana perjuangan agen dalam mendobrak potensi sesuai dengan keunggulan sumber daya yang dimilikinya. Arena dalam penelitian ini adalah pernikahan yang dibagi dalam dua bentuk, social field berupa pernikahan adat Mandailing dan intellectual field yakni pernikahan berbasis syariat. Dua hal ini berkelindan dalam diri setiap agen dan selalu dikaitkan dengan agen lokal maupun struktur agama melalui status superioritas dan inferioritas.

Agen dalam ranah pernikahan termasuk dalam kategori ranah sosial karena masih dimotori oleh superioritas elite lokal dibandingkan ranah intelektual yang dimiliki agen seputar praktik pernikahan berbasis syariat. Sampai di sini, arena dapat dimaknai sebagai kekuatan yang mendefinisikan situasi dan posisi agen dan struktur (Jenkins 2016:125).

Modal adalah probabilitas kemampuan agen dalam mengontrol nasibnya. Modal yang dianut agen diklasifikasi ke dalam empat bentuk: 1) modal sosial, yakni kemampuan dalam membangun hubungan sosial; 2) modal finansial, yakni kemampuan dalam merealisasikan kebutuhan ekonomi; 3) modal kultural, yakni kemampuan berupa taraf pengetahuan yang legitim; dan 4) modal simbolik, yaitu kemampuan yang berakar pada martabat dan prestise.

Peneliti tidak dapat memungkiri bahwa setiap agen memiliki keempat modal tersebut. Akan tetapi, taraf modal yang dimiliki agen belum mampu memenuhi kriteria praktik pernikahan syar'i, atau bisa dikatakan ketidakstabilan modal agen dalam menyaingi superioritas agen elite lokal. Kendati demikian, agen mampu melakukan negosiasi berupa penyesuaian-penyesuaian kemampuan modal yang dimiliki dengan memangkas prosedur pernikahan menjadi semikompleks. Ilustrasi tersebut mengindikasikan bahwa posisi agen elite lokal mendominasi agen lainnya.

Proses dialektis antara habitus, ranah, dan modal yang dianut oleh agen dan struktur disebut sebagai praktik. Pada penelitian ini, praktik pernikahan di Kota Padangsidimpuan adalah proses dialektis agen lokal dan struktur agama dengan segala corak kecenderungan, wahana, dan taraf modal yang secara adaptif saling bertemu dan saling memengaruhi atau menstrukturkan.

Tampak dalam praktek pernikahan di Kota Padang Sidempuan ini, dalam kontestasi nilai agama dan nilai lokal, lebih didominasi nilai lokal. Dialog antara nilai agama dengan nilai lokal masih membutuhkan proses negosiasi budaya untuk menyeimbangkan kekuatan antar kedua nilai yang diacu oleh masyarakat. Keberimbangan rujukandapat tercapai manakala: 1 ) otoritas sosial mendahului otoritas pikiran, sehingga menimbulkan determinasi struktural; dan 2) wawasan terdahulu justru mendiskreditkan fokus analitis antara dua variabel otoritas (Liddle 1997:19-20).

Dengan demikian, keunikan suatu praktik pernikahan yang berlangsung setidaknya memuat dua aspek penting: 1) akumulasi modal dan status agen menentukan taraf kekuatan simbolik; dan 2) kompetensi personal menentukan langkah strategis untuk meloloskan prasyarat praktik yang dikehendaki (Riawati 2017:28). 


\section{Alternatif Reproduksi Sosial: Upaya Pembiasaan Praktik Pernikahan Agama}

Praktik pernikahan adat Mandailing telah lama dilestarikan sebagai kebudayaan yang mengakar pada masyarakat. Bourdieu menyebut kestabilan tatanan sosial tersebut sebagai "doxa" karena telah menghegemoni individu secara alamiah (Harker et al. 2005:xxi). Pelestarian pernikahan adat akan tetap berlangsung sebagai upaya memproteksi eksistensi budaya (Dalimunthe, 2016).

Meskipun demikian, selalu ada celah terjadinya modifikasi budaya. Celah itu dinamakan akulturasi. Akulturasi adalah proses internalisasi suatu unsur budaya lama dengan budaya baru tanpa menghilangkan jejak otentisitas atau keasliannya (Koentjaraningrat 1993:248). Proses akulturasi dibagi menjadi: 1) substitusi, yakni pergantian unsur kebudayaan yang lebih fungsional; 2) sinkretisme, yaitu memadukan unsurunsur lama dan baru, serta menghasilkan sistem yang lebih modern dan bermakna; 3) adisi, yaitu perpaduan unsur lama dan tanpa merubah strukturnya; 4) dekulturasi, yakni ternegasikannya esensi dari suatu kebudayaan; 5) originalisasi, adalah dibutuhkannya unsur baru atas perubahan kondisi; dan 6) penolakan, yakni muatan unsur baru menciptakan perubahan yang justru memicu resistansi (Haviland and Soekadijo 1985).

Penelitian Anisah (2017), Dalimunthe (2016), Harahap (2016) dan Nurhakimah (2018) membuktikan kuatnya arus akulturasi, disertai prinsip humanisasi dan liberalisasi yang berbasis transendental (Jurdi 2010:46) juga turut memengaruhi praktik pernikahan adat.
Oleh karena itu, diperlukan serangkaian pembiasaan, yang memproses suatu perilaku menjadi kebiasaan seseorang (Priyatna 2013:62). Dualitas agen dan struktur dapat diselesaikan melalui penawaran alternatif pernikahan syar'i yang sebetulnya telah dikenal di kalangan umat Islam. Pelaksanaannya pun terbilang simpel dan mampu mereduksi beberapa substruktur pernikahan yang dapat menguras modal agen. Peneliti menyadari bahwa tawaran ini cenderung mengarah pada perspektif para salaf dengan gejala eksklusivisme dan fundamentalismenya. Di sisi lain, kecenderungan itu juga dapat diikhtiarkan sebagai egalitarianisme Islam, yakni proporsionalitas agen dalam mengekspresikan kehendak dan kecintaannya pada manusia dan Sang Pencipta (Abidin dan Safe'i 2003:103).

Peneliti menawarkan rekomendasi untuk memaksimalkan pembiasaan ajaran agama dengan tiga aspek penting. Aspek signifikansi, penelitian ini berupaya: 1) mere-branding praktik pernikahan yang original dengan kembali pada aturan syar'i; 2) reinterpretasi praktik pernikahan secara holistik; dan 3) pengembangan teori praktik sosial Bourdieu dalam riset praktik pernikahan masyarakat lokal.

Aspek implikasi, antara lain: 1) input bagi organisasi/perusahaan yang bergerak dalam jasa wedding organizer untuk mengidentifikasi dan meng-upgrade tata laksana pernikahan syar'i; dan 2) input bagi elite agama mendiskursifkan ranah pernikahan dengan posisi yang lebih proporsional dalam menyikapi pernikahan adat dan syariat.

Adapun dari aspek intervensi, antara lain: 1) input bagi aparatur pemerintahan untuk merevisi materi kurikulum agama dalam mempraktikkan 
pernikahan yang tidak terbatas pada aspek fiqih tetapi juga hadits; dan 2) aparatur KUA dapat mensosialisasikan fungsionalitas pernikahan syar'i sebagai alternatif bagi calon pasangan melalui proses bimtek pernikahan.

Sudah sewajarnya agen yang siap menikah dan memilih pasangan karena pilihan rasionalnya, bukan karena tekanan sosial (Himawan 2019; Lee et al. 2018). Oleh karena itu, penting untuk mengetahui faktor-faktor mendasar praktik pernikahan yang berlangsung di lingkungan masyarakat, sehingga dapat dirancang strategi untuk mensosialisasikan prinsip-prinsip Islam dengan akurat oleh keluarga dan cendekiawan dalam program yang terukur melalui pelatihan, edukasi, dan rekomendasi (Laeheem 2018).

\section{Kesimpulan}

Pernikahan dalam bingkai syariat dan kultural memiliki elemen konsepsional yang cenderung berbeda dan kadangkala mengalami distorsi dalam pelaksanaannya. Syariat mengatur praktik pernikahan berlandaskan pada aspek adab, batasan, dan konsekuensi-konsekuensi syariat yang termaktub dalam ayat-ayat suci dan ijma. Sedangkan aspek kultural mengorganisir praktik pernikahan sebagaimana yang dikonstruksi oleh leluhur terdahulu dan diwariskan sampai sekarang.

Pernikahan menjadi relevan dalam teori praktik sosial Bourdieu di mana terdapat dualitas antara agen yang dikoordinasi oleh elite lokal dengan struktur agama yang menganut kekuatan esensi dan prosedur tersendiri. Proses dialektis tersebut melibatkan kekuatan habitus, modal, dan arena masing-masing elemen sosial yang terlibat.
Masyarakat lokal di Padang Sidempuan mayoritas beragama Islam dan beretnik Mandailing serta dalam praktik pernikahannya telah mengalami perubahan. Akan tetapi disadari bahwa agama tidak mengizinkan adanya penyimpangan. Mereka juga meyakini bahwa pernikahan syar'i cukup mudah untuk dilakukan dibandingkan dengan pernikahan kultural dengan prasyarat yang relatif kompleks.

Kekerasan simbolik dimaknai Bourdieu sebagai sistem simbolisme dan makna yang determinatif, dilegitimasi melalui relasi kekuasaan, dan direproduksi secara sistematis oleh pemiliknya (Jenkins 2016:157). Praktik pernikahan di Kota Padang Sidempuan membuktikan bahwa kuasa simbolik masih dominan mengontrol para agen. Di sisi lain, pernikahan adalah ritual sakral yang membutuhkan sikap kesukarelaan dan kesanggupan modal seseorang. Meskipun ada jalan negosiasi, tetapi perlu disikapi dengan bijak oleh kedua belah pihak tanpa memonopoli pihak lainnya yang menanggung beban pernikahan. Karena dari negosiasilah dapat dirumuskan secara logis format pernikahan yang dikehendaki.

Tanpa bermaksud mendiskreditkan pernikahan ala adat-istiadat, penelitian ini berguna untuk mempromosikan tata cara pernikahan syar'i dengan kadar kompleksitas yang minim. Selain meringankan beban finansial, tetapi juga meningkatkan nalar spiritual agen dalam mengamalkan syariat. Di sisi lain, penelitian ini diharapkan dapat berkontribusi dalam mengembangkan kajian-kajian sosial kontemporer dalam bingkai keislaman, sembari menyegarkan kembali ingatan pembaca tentang eksistensi 
Sosiologi Islam yang patut diperhitungkan di kancah akademik.

Kendati tulisan ini adalah upaya baru dalam memotret praktik pernikahan secara sosiologis, namun penelitian ini dapat dikritisi dan dikomparasikan dengan praktik pernikahan yang lebih bervariatif. Bagi peneliti, respon dari sesama akademisi sangat diperlukan untuk mengembangkan studi Sosiologi ke arah yang lebih progresif.]

\section{Daftar Pustaka}

Abidin, Zainal dan Ahmad Safe'i. 2003. Sosiophologi: Sosiologi Islam Berbasis Hikmah. Bandung: Pustaka Setia.

Adib, Muhammad. 2012. "Agen dan Struktur dalam Pandangan Piere Bourdieu." BioKultur 1(2):91-110.

Adiningsih, A. Mega Utami. 2016. "Tinjauan Hukum Islam tentang Dui' Menre (Uang Belanja) dalam Perkawinan Adat Bugis." Universitas Hasanuddin, Makassar.

Amalia, Annisa Rizky. 2017. "Tradisi Perkawinan Merariq Suku Sasak di Lombok: Studi Kasus Integrasi Agama dengan Budaya Masyarakat Tradisional." Universitas Islam Negeri Syarif Hidayatullah, Jakarta.

Anas, Azwar. 2010. "Konsep Mahar dalam 'Counter Legal Draft' Kompilasi Hukum Islam (CLD KHI)." Universitas Islam Negeri Syarif Hidayatullah, Jakarta.

Anggito, Albi dan Johan Setiawan. 2018. Metodologi Penelitian Kualitatif. Sukabumi: Jejak.

Anisah, Siti. 2017. "Adat Istiadat Perkawinan Suku Mandailing di Kecamatan Ranto Baek Mandailing Natal 1990-2010." Universitas Sumatera Utara, Medan.
Anwar, Khoirul. 2017. "Peran Kiai dalam Pemilihan Calon Pasangan bagi Santri Berdasarkan Konsep Takzim Perspektif Struktural Fungsional (Studi di Pondok Pesantren Pendidikan Perguruan Agama Islam [PPAI] Darussalam Kopanjen Kabupaten Malang)." Universitas Islam Negeri Maulana Malik Ibrahim, Malang.

Arifin. 2018. "Motif Pelaksanaan Resepsi Pernikahan Perspektif Hukum Islam di Kecamatan Rangkasbitung Kabupaten LebakBanten." Universitas Islam Negeri Syarif Hidayatullah, Jakarta.

Atabik, Ahmad dan Khoridatul Mudhiah. 2014. "Pernikahan dan Hikmahnya Perspektif Hukum Islam." Yudisia: Jurnal Pemikiran Hukum dan Hukum Islam 5(2):286-316.

al-Atsari, Abu Ishaq al-Huwaini dan Ibnul Qayyim al-Jauziyah. 2007. Tuntunan Lengkap Pernikahan. Pekalongan: Maktabah Salafy Press.

Aziz, Safrudin. 2017. "Tradisi Pernikahan Adat Jawa Keraton Membentuk Keluarga Sakinah." Ibda: Jurnal Kajian Islam dan Budaya 15(1):22-41.

Baaz, Abdul Aziz bin Abdullah bin dan Muhammad bin Shalih al-Utsaimin. 2002. Bid'ahBid'ah dalam Pernikahan yang dianggap Biasa. Surakarta: At-Tibyan.

Bourdieu, Pierre. 1986. Distinction: A Social Critique of the Judgement of Taste. New York: Routledge.

Bourdieu, Pierre. 1993. The Field of Cultural Production: Essays on Art and Leissure. New York: Columbia University Press.

Bryman, Alan. 2004. Social Research Methods. New York: Oxford University Press. 
Dalimunthe, Al Maysita. 2016. "Eksistensi Perkawinan Adat pada Masyarakat Mandailing di Kota Medan." Premise Law Jurnal 13.

Dalimunthe, Deni Eva Masida. 2012. "Tor-Tor pada Upacara Adat Perkawinan Masyarakat Tapanuli Selatan." Gesture: Jurnal Seni dan Tari 1(1):1-11.

Elvira, Rika. 2014. “Ingkar Janji Atas Kesepakatan Uang Belanja (Uang Panai') dalam Perkawinan Suku Bugis Makassar." Universitas Hasanuddin Makassar, Makassar.

Hairani. 2018. "Tradisi Pernikahan Anak Perempuan Sayyid di Desa Cikoang Kecamatan Mangarabombang Kabupaten Takalar dalam Perspektif Hukum Islam." Universitas Negeri Makassar, Makassar.

Harahap, Hamdani. 2016. "Perubahan Adat dan Budaya Mandailing Kajian: Tradisi Lisan." Universitas Sumatera Utara, Medan.

Harahap, Ulul Ma'rifah. 2017. "Komunikasi Keluarga Batak Mandailing dalam Mempertahankan Tradisi Perkawinan Pariban (Studi pada Keluarga Batak Mandailing di Kabupaten Mesuji." Universitas Lampung, Lampung.

Harker, Richard, Cheelen Mahar, and Chris Wilkes, eds. 2005. (Habitus X Modal) + Ranah = Praktik: Pengantar Paling Komprehensif Kepada Pemikiran Pierre Bourdieu. Yogyakarta: Jalasutra.

Haryatmoko. 2016. Membongkar Rezim Kepastian: Pemikiran Kritis Post-Strukturalis. Yogyakarta: Kanisius.

Haviland, William A. dan R. G. Soekadijo. 1985. Antropologi Jilid 2. Jakarta: Erlangga.

Himawan, Karel Karsten. 2019. "Either I Do or I Must: An Exploration of the Marriage Attitudes of Indonesian Singles." The Social Science Journal 56(2):220-27.
Huda, Mahmud dan Nova Evanti. 2019. "Uang Panaik dalam Perkawinan Adat Bugis Perspektif 'Urf (Studi Kasus di Kelurahan Batu Besar Kecamatan Nongsa Kota Batam)." Jurnal Hukum Keluarga Islam 3(2):133-58.

Ilman, Muhamad. 2016. "Tradisi Pembayaran Uang Pelangkah dalam Perkawinan." Universitas Islam Negeri Syarif Hidayatullah, Jakarta.

Jauhari, Imam B. 2012. Teori Sosial Proses Islamisasi dalam Sistem Ilmu Pengetahuan. Yogyakarta: Pustaka Pelajar \& STAIN Jember Press.

Jenkins, Richard. 2016. Membaca Pikiran Bourdieu. Yogyakarta: Kreasi Wacana.

Jurdi, Syarifuddin. 2010. Sosiologi Islam dan Masyarakat Modern: Teori, Fakta, dan Aksi Sosial. Jakarta: Kencana.

Kartikasari, Hesti. 2019. "Hubungan Hukum Islam dan Hukum Adat Pada Larangan Pernikahan di Desa Karangsari Kecamatan Pengasih Kabupaten Kulon Progo." Universitas Islam Negeri Sunan Kalijaga, Yogyakarta.

Koentjaraningrat. 1993. Masalah Kebudayaan dan Integrasi Nasional. Jakarta: UI-Press.

Koentjaraningrat. 2004. Manusia dan Kebudayaan di Indonesia. Jakarta: Djambatan.

Krisna, Eva dan Fefa Srila Desti. 2015. "Religiusitas dan Konsep Pernikahan Suku Bangsa Mandailing pada Upacara Hata Pangupa." Widyaparwa Ournal Ilmiah Kebahasaan Dan Kesastraan) 43(1):55-64.

Kuntowijoyo. 2001. Muslim tanpa Masjid: EseiEsei Agama, Budaya, dan Politik dalam Bingkai Strukturalisme Transendental. Bandung: Mizan. 
Laeheem, Kasetchai. 2018. "Approaches to Promoting Islamic Ethics in Adherence to the Faith among Thai Muslim Youths in Pattani Province, Southern." Kasetsart Journal of Social Sciences 30(2):1-6.

Larasaty, Wulan, Marzam Marzam, dan Syeilendra Syeilendra. 2013. "Persepsi Masyarakat terhadap Pertunjukan Organ Tunggal Malam Hari dalam Acara Pernikahan di Tebo." Jurnal Sendratasik 2(1):81-90.

Lee, Sharon M., Feng Hou, Barry Edmonston, dan Zheng Wu. 2018. "Group Size and Secular Endogamy among the Religiously Unaffiliated in Canada." Social Science Research 74:196-209.

Liddle, R. William. 1997. Islam, Politik, dan Modernisasi. Jakarta: Pustaka Sinar Harapan.

Mathlub, Abdul Majid Mahmud. 2005. Hukum Perkawinan dalam Islam. Solo: Era Intermedia.

Muhadi, Dedi. 2015. "Tradisi Perjodohan dalam Komunitas Pesantren (Studi pada Keluarga Kyai Pondok Buntet Pesantren)." Universitas Islam Negeri Syarif Hidayatullah, Jakarta.

Naim, Abdul Haris. 2008. Fiqih Munakahat. Kudus: Sekolah Tinggi Agama Islam Negeri Kudus.

Nasution, Ali Raja. 2011. "Penetapan Mahar dalam Adat Mandailing dan Dampaknya terhadap Kelangsungan Pernikahan Ditinjau menurut Hukum Islam (Studi Kasus di Desa Tambusai Barat Kecamatan Tambusai Kabupaten Rokan Hulu)." Universitas Islam Negeri Sutan Syarif Kasim, Pekanbaru.

Noorthaibah, Noorthaibah. 2012. "Refleksi Budaya Muslim pada Adat Perkawinan
Budaya Banjar di Kota Samarinda." Fenomena 4(1):17-30.

Nurhakimah. 2018. "Pesan Komunikasi Islam dalam Syair Seni Tarian Tor-Tor pada Pernikahan Adat Mandailing di Kabupaten Mandailing Natal." Universitas Islam Negeri Sumatera Utara, Medan.

Nuruddin, Amir dan Azhari Akmal Tarigan. 2004. Hukum Perdata Islam di Indonesia. Jakarta: Kencana.

Prawiro, Dimas. 2013. "Implementasi Penetapan Uang Hantaran Nikah dalam Perspektif Hukum Islam (Studi pada Masyarakat Kelurahan Pulau Kijang Kecamatan Reteh Kabupaten Indragiri Hilir)." Universitas Islam Negeri Sultan Syarif Kasim, Pekanbaru.

Priyatna, Haris. 2013. Kamus Sosiologi: Deskriptif dan Mudah Dipahami. Bandung: Nuansa Cendekia.

Rahayu, Sri and Yudi Yudi. 2015. "Uang Nai': Antara Cinta dan Gengsi." Jurnal Akuntansi Multiparadigma 6(2):224-36.

Riawati, Selly. 2017. Saduran Outline of a Theory of Social Practice Karya Pierre Bourdieu. Bandung: Ultimus.

Ritzer, George dan Goodman J. Douglas. 2011. Teori Sosiologi Modern. Jakarta: Kencana Predana Media Group.

Sekaran, Uman. 1993. Research Methods for Business: A Skill Building Approach. New York: John Wiley \& Sons Inc.

Shodiq, Muhammad. 2008. "Pandangan Hukum Islam terhadap Ritual Pra dan Pasca Nikah bagi Kedua Mempelai (Studi Kasus di Desa Katekan Ngadirejo Temanggung)." Universitas Islam Negeri Sunan Kalijaga, Yogyakarta. 
Simanjuntak, Bungaran Sitorus. 2006. Struktur Sosial dan Sistem Politik Batak Toba Hingga 1945: Suatu Pendekatan Antropologi Budaya dan Politik. Jakarta: Yayasan Obor Indonesia.

Soekanto, Soerjono. 2005. Sosiologi Suatu Pengantar. Jakarta: Rajawali Press.

Swartz, David. 1997. Culture and Power: The Sociology of Pierre Bourdieu. Chicago: University of Chicago Press.

Tutik, Titik Triwulan. 2006. Pengantar Hukum Perdata di Indonesia. Jakarta: Presentasi Pustaka.
Wekke, Ismail Suardi. 2013. "Islam dan Adat: Tinjauan Akulturasi Budaya dan Agama dalam Masyarakat Bugis." Analisis: Jurnal Studi Keislaman 13(1):27-56.

Wulansari, Catharina Dewi. 2013. Sosiologi: Konsep dan Teori. Bandung: Refika Aditama.

Ypes, W. K. H. 1932. Bijdrage Tot de Kennis van de Stamverwantschap, de Inheemsche Rechtsgemeenschappen En Het Grondrecht Der Toba- En Dairi-Bataks. Leiden: Uitgeven door de Adatrechtstichting.

Yuniariandini, Amanta. 2016. "Kebahagiaan Pernikahan: Pertemanan dan Komitmen." Psikovidya 20(2):53-58. 
This page intentionally left blank. 